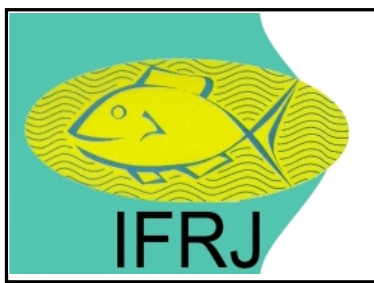

Available online at: http://ejournal-balitbang.kkp.go.id/index.php/ifrj

e-mail:ifrj.puslitbangkan@gmail.com

INDONESIANFISHERIES RESEARCHJOURNAL

Volume 26 Nomor 2 December 2020

p-ISSN: 0853-8980

e-ISSN: 2502-6569

Accreditation Number RISTEK-BRIN: 85/M/KPT/2020

\title{
REPRODUCTIVE BIOLOGY OF LONGTAIL TUNA (Thunnus tonggo) IN THE JAVA SEA
}

\author{
Thomas Hidayat ${ }^{* 1,2}$, Mennofatria Boer ${ }^{2}$, Mohammad Mukhlis Kamal ${ }^{2}$, Zairion ${ }^{2}$ and Ali Suman ${ }^{1}$ \\ ${ }^{1}$ Research Institute for Marine Fisheries, Jl. Raya Bogor KM 47 Nanggewer Mekar, Cibinong, Bogor-Indonesia \\ ${ }^{2}$ Faculty of Fisheries and Marine Science, IPB University, Bogor; JI. Lingkar Kampus IPB Dramaga, Bogor-Indonesia \\ Received; March 04-2019 Received in revised from August 25-2020; Accepted September 03-2020
}

\section{ABSTRACT}

Longtail tuna (Thunnus tonggol) is one of common economically important pelagic fish species in Indonesia. The objective of this study is examining the biology of reproduction, consisting of length of weight relationship, sex ratio, maturity stage, gonado somatic index (GSI), length at first capture, and length at first maturity and spawning pattern. A total of 633 longtail tuna, ranging 29-58 $\mathrm{cmFL}$ and consisting of 293 males and 340 females, were collected from the Java Sea between April 2018 and March 2019. The results showed that the longtail tuna growth pattern was isometric. The sex ratio was not significantly different between male and female. The length of first capture longtail tuna of drift gillnet $(43.2 \mathrm{cmFL})$ was bigger than the length at first maturity $(42,3 \mathrm{cmFL})$. This indicates that the most of longtail tuna caught by drift gillnet have already spawned. The peak's spawning season occurred in May and November, with fecundity ranging from 783,597 - 1,579,160 eggs. Longtail tuna has multiple spawning pattern.

\section{INTRODUCTION \\ Longtail tuna (Thunnus tonggol) is an epipelagic}

Keywords: Biology; Thunnus tonggol; spawning season; the Java Sea species in tropical and subtropical waters in the Indo Pacific region between $47^{\circ} \mathrm{N}$ to $33^{\circ} \mathrm{S}$. This species can grow to a maximum size of total lengths of 142 $\mathrm{cm}$ (TL) and weight $35.9 \mathrm{~kg}$ (Froese \& Pauly, 2020). Longtail tuna is quite unique compared to other Thunnus species that are commonly found in the deep sea. This species is almost exclusively confined to neritic areas less than $200 \mathrm{~m}$ depth, but generally less than $50 \mathrm{~m}$, and is rarely found offshore (Yesaki, 1994). According to Cheunpan (1984), longtail tuna is usually caught in the waters around $15-30$ nautical miles from shore land at depths of $20-45 \mathrm{~m}$. The fish commonly live in the waters with temperatures of 1631 !, avoiding low salinity and high turbidity. Longtail tuna is found in Indo Pacific waters from southern Japan, the Philippines, Papua New Guinea to Australia and westward from Indian waters, the Arabian Peninsula, the Red Sea to the Somalian coast. (Collete \& Nauen, 1983). In Indonesian waters, longtail tuna is commonly found along the Java Sea, the Natuna Sea/southern part of the South China Seas to the Malacca Strait.

Longtail tuna (Thunnus tonggol) in the Java Sea is commonly performed as fish schools with other neritic tuna kawa-kawa (Euthynnus affinis) and frigate tuna (Auxis thazard). Landing data in Pekalongan Fishing Port, one of the largest fishing ports in the north coast of Java, indicates that longtail tuna has the largest proportion among the other neritic tuna at about $48 \%$ (Pekalongan Fishing Port Nusantara 2016). This annual report showed that the landed fish was mainly caught by two types of fishing gears, comprising $33 \%$ from drift gillnet and $67 \%$ from purse seine (Wujdi \& Suwarso, 2014). The annual national catch statistics of longtail tuna increased from 95,325 tons in 2006 and reached its peak production with 117,783 tons in 2011 then declined to 84,022 tons in 2012 to its lowest at 65,651 tons in 2016 (DGCF, 2017). Longtail tuna catch in the Java Sea reached 12,553 tons or $19.2 \%$ from nasional catch andlongtail tuna catch in Pekalongan was $19.68 \%$ from the Java Sea catch, or equal to $1.80 \%$ of national catch (DGCF, 2017).

Worldwide study on biological parameters of this species has been published by several authors, such as in Pacific Oceania (Wilson, 1981), west Thailand waters (Yesaki, 1982), Gulf of Thailand (Cheunpan, 1984), Manglore East Indian waters (Muthiah, 1985), north and eastern Australia (Griffiths et al., 2010), Taiwan (Wei et al., 2011), Persian Gulf (Hedayatifard, 2007; Kaymaran et al., 2013), along Indian coastal waters (Abdussamad et al., 2012; Koya et al., 2018), 
and the South China Sea (Hidayat \& Noegroho, 2018). Nevertheless, studies of this species on the Java Sea are still limited and need to be updated.

The focus of this study is to provide information on the reproductive biology of longtail tuna that could provide an important reference to describe the stock status as the baseline to build management guidance in the Java Sea and its adjacent waters.

\section{MATERIALS AND METHODS Data Collections}

Samples of longtail tuna were collected from drift gillnet and mini purse seine fishing that were operated in the Java Sea (Figure 1). Random samples were collected monthly from April 2018 to March 2019 at Pekalongan Fishing Port, Central Java, Indonesia, with geographical position 650'42"S- 65' 44 "S and
1093'55"E- 10942'19"E. Whole weight (to the nearest $0.1 \mathrm{~g}$ ) and fork length (to the nearest $0.1 \mathrm{~cm}$ ) were measured and collected as the baseline of this study. Gonads were removed and weighed to the nearest $0.1 \mathrm{~g}$, then preserved in Gilson's fluid for further examination on fecundity and oocyte diameter. Furthermore, for histological analysis, gonad samples were preserved in formalin $4 \%$. Sample analyses were conducted at the Laboratory of Research Institute Marine Fisheries, Cibinong Bogor. Measuring biological aspects (length, weight, and gonad maturity) were conducted in the Fishery Laboratory at the Pekalongan Fishing Port, Central Java. Analysis of fecundity and histological examination of ovaries were conducted at the laboratory of Research Institute Marine Fisheries, Cibinong Bogor. The determination of gonad maturity stages followed the criteria of I to $\mathrm{V}$ (Holden \& Raitt, 1974).

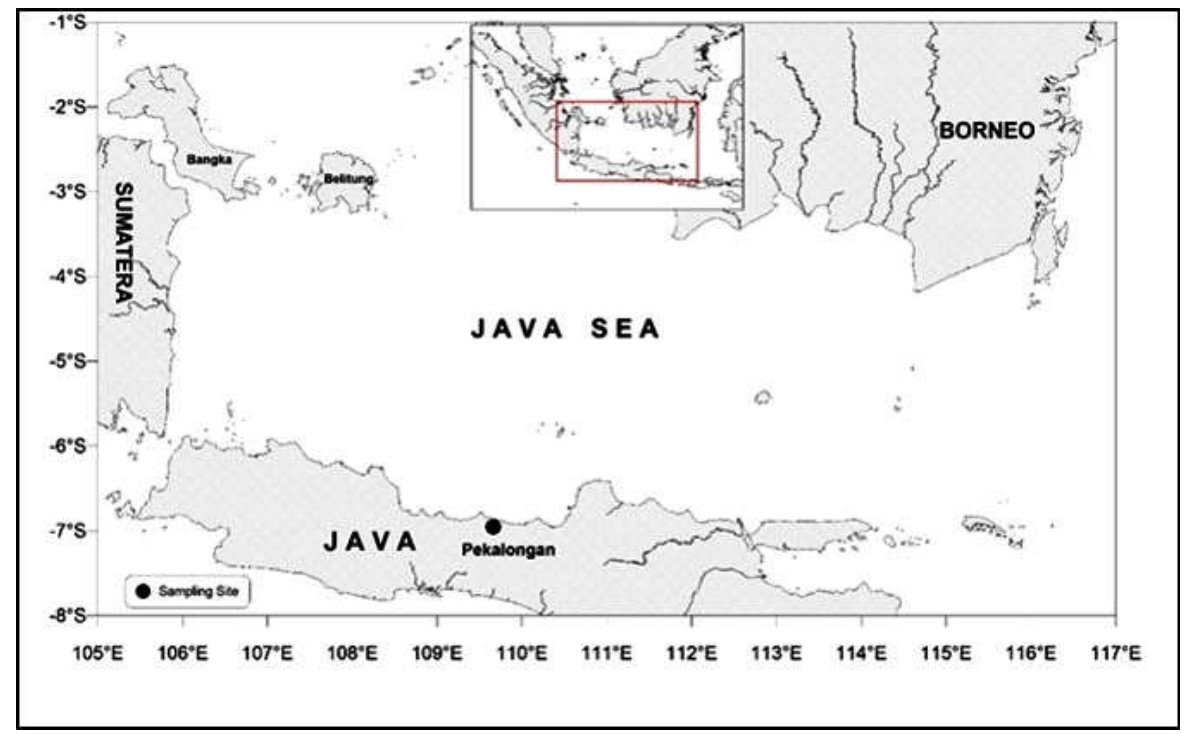

Figure 1. Sampling site of longtail tuna in the Java Sea.

\section{Data Analyses}

The Length-Weight relationship was determined by Effendie (2002):

$W=a L^{b}$

Where $W$ is the total weight of fish (gram), $L$ is the fork length $(\mathrm{cm}), a$ and $b=$ constants. In order to verify if calculated $b$ was significantly different from 3 (allometric), the Student $t$-test (Sokal \& Rohlf, 1987) was conducted.

The sex ratio was expressed as:

$X=M: F$
Where $X$ is the sex ratio, $M$ is the number of male fish observed, and $F$ is the number of female fish observed. Chi-square $\left(X^{2}\right)$ test was used to examine the homogeneity of the sex ratio. The sex ratio was tested by chi-square according to Sugiyono (2004) as follows:

$$
X^{2}=\sum_{i=l}^{k} \frac{(f o-f n)^{2}}{f n}
$$

Where $X^{2}=$ Chi-square, $f 0=$ observed frequency, and $f n=$ expected frequency, with the null hypothesis $\left(\mathrm{H}_{0}\right)$ : there is no significant difference between the number of male and female fish.

The length at first capture $(L C)$ is determined based on the relationship between the length of the fish (X- 
axis) and the number of fish (Y-axis) to form an $\mathrm{S}$ curve. The estimate length at first capture $(L c)$ was estimated using the following formula by Sparre \& Venema (1998):

$$
\begin{aligned}
& S_{L} e^{e s t}=\frac{1}{1+\exp \left(S_{1}-S_{2} * L\right)} \\
& L_{50 \%}=\frac{S_{1}}{S_{2}}
\end{aligned}
$$

Where $S_{L}$ est is a logistic curve, $S_{1}$ and $S_{2}$ are constants.

Estimation of the length at first maturity $(L m)$ used the logistic function approach (King, 1995) with the equation:

$$
P_{L m}=\frac{1}{1+\exp (a L+b)}
$$

Where $P_{L m}$ is the proportion of the number of mature fish with length $L$ to the number of immature fish with length of $L a$ and $b$ are the curve parameters $(a<0$ and $b>0$ ), so that the length at $50 \%$ mature gonad $(L m)$ is the same as $-a / b$.

The gonadosomatic index (GSI) is a comparison of gonad weight to fish weight. This index value over time will get greater until reaching the peak limit, then there will be a decrease (King, 1995). By knowing this GSI, the fish spawning period can be estimated. The GSI was analyzed according the Effendie formula (2002):

$G S I=W_{g} / W_{t} \times 100 \%$

Where $G S I$ is gonadosomatic index (\%), $W_{g}=$ weight of gonad (gr), $W_{t}=$ total weight of fish (gr).

The fecundity analysis was conducted on adult female fish with gonad maturity stage of III and IV. The measurements of diameter size and number of oocytes were done by using a microscope $4 \times 10$. The observation of the number and distribution of oocyte size used egg samples as much as 0.5 grams.
The fecundity was calculated gravimetrically by the formula Holden \& Raitt (1974):

$F=n . G / g$

Where $F$ is fecundity, $n=$ number of eggs in subsample, $G=$ gonad weight, $g=$ weight of gonad subsample (0.5 gram).

The relationships between fecundity $(F)$ and length (L) or weight were expressed by the following equation (Sujatha et al., 2014):

$F=a L^{b}$

Where $F$ is the fecundity of eggs, $L$ is fork length (cm) or fish weight $(\mathrm{g})$, $a$ and $b=$ constants.

\section{RESULTS AND DISCUSSION Results}

\section{Length-Weight Relationship}

A total 633 specimens of longtail tuna were investigated. The length ranged 29-58 cmFL, and weight $433-3190 \mathrm{~g}$, the unisex the length-weight relationship of $T$. tonggol was estimated as $\mathrm{W}=0.019 \mathrm{~L}^{2.9838}\left(\mathrm{R}^{2}=0.9677\right)$, where the value of $b$ was 2.9838 (Figure 2).

The next analysis used Student's $t$-test on the value of $b$ of the whole samples of male and female longtail tuna, with $95 \%$ confidence level $(p=0.05)$. The value of tcount $=0.0000170738$ was smaller than $t_{\text {table }}$ $=1.984$. This result showed that $b$ was not significantly different from 3, which indicated isometric growth pattern. The isometric length-weight relationship means the weight gain is proportional to the increase in length (Effendi, 2002).

The observations of monthly length-weight parameters of longtail tuna obtained are as in Table 1 below. It shows that all monthly length-weight relationships of longtail tuna were isometric (after conducting $t$-test). 


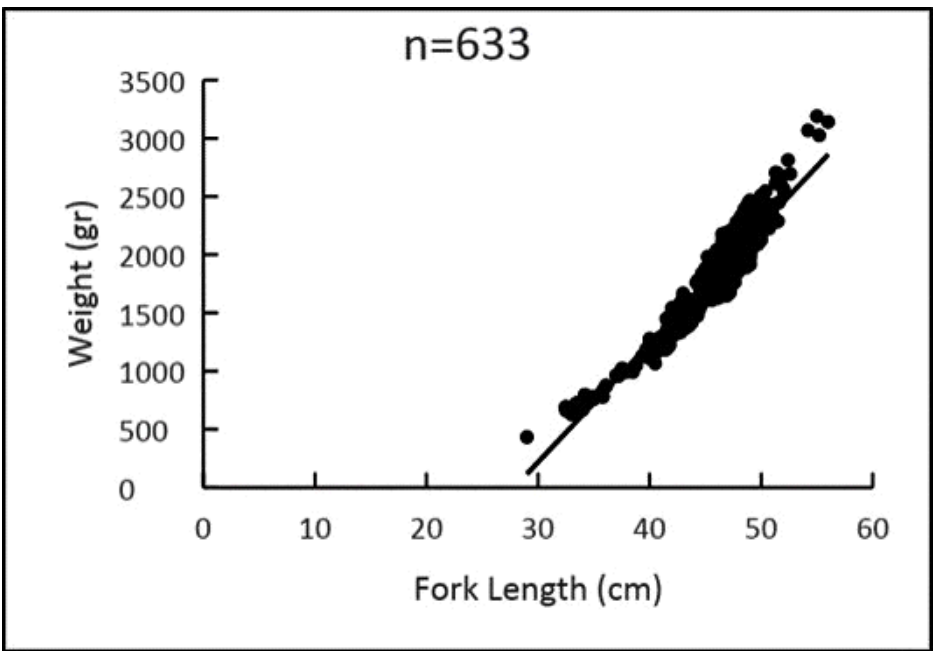

Figure 2. Length-weight relationships of longtail tuna in the Java Sea.

Table 1. Monthly length-weight parameters of longtail tuna in the Java Sea

\begin{tabular}{lccccccc}
\hline \multirow{2}{*}{ Month } & $\boldsymbol{n}$ & $\boldsymbol{a}$ & $\boldsymbol{b}$ & $\boldsymbol{R}^{2}$ & \multicolumn{2}{c}{$\boldsymbol{t}$-test } & \multirow{2}{*}{ Growth } \\
\cline { 1 - 3 } & & & & & tcount & ttable & \\
\hline Apr & 47 & 0.0563 & 2.7310 & 0.820 & 0.000245 & 2.021 & isometric \\
May & 48 & 0.0454 & 2.7702 & 0.894 & 0.000218 & 2.021 & isometric \\
Jun & 36 & 0.0212 & 2.9682 & 0.969 & 0.000045 & 2.042 & isometric \\
Jul & 58 & 0.0134 & 3.0819 & 0.822 & 0.000082 & 2.021 & isometric \\
Aug & 37 & 0.0717 & 2.6571 & 0.826 & 0.000360 & 2.042 & isometric \\
Sep & 54 & 0.0279 & 2.8945 & 0.923 & 0.000100 & 2.021 & isometric \\
Oct & 51 & 0.0989 & 2.5684 & 0.680 & 0.000410 & 2.021 & isometric \\
Nov & 52 & 0.1335 & 2.4848 & 0.709 & 0.000520 & 2.021 & isometric \\
Dec & 54 & 0.0371 & 2.8047 & 0.990 & 0.000235 & 2.021 & isometric \\
Jan & 50 & 0.0189 & 2.9938 & 0.980 & 0.000008 & 2.021 & isometric \\
Feb & 97 & 0.0220 & 2.9486 & 0.978 & 0.000065 & 1.984 & isometric \\
Mar & 49 & 0.0208 & 2.9626 & 0.975 & 0.000043 & 2.021 & isometric \\
\hline
\end{tabular}

\section{Sex Ratio}

The sex ratio of all male and female specimens was 0.9:1. A chi-square test accepted the null hypothetical ratio resulted, which was no significantly difference between male and female with 95\% confidence level $(p=0.05)$. It means the sexes were equally distributed in the population.

\section{Gonadosomatic Index}

The average of monthly gonadosomatic index (GSI) for female ranged from 0.08-4.4 and for male ranged
1.0-5.5. The GSI for male and female had two peaks with the highest indeces were in April and October then decreased in the following months that indicated the spawning happened in May and November (Figure 3.)

\section{Gonad Maturity Stage}

The results showed that the monthly distribution of gonad maturity stage I to IV are fluctuated. Gonad maturity stage IV of male and female longtail tuna fish was found every month, with the two highest percentage occuring in September and October (Figure. 4 and 5). 
Reproductive Biology of Longtail Tuna (Thunnus tonggol) in the Java Sea (Hidayat, T., et al.)

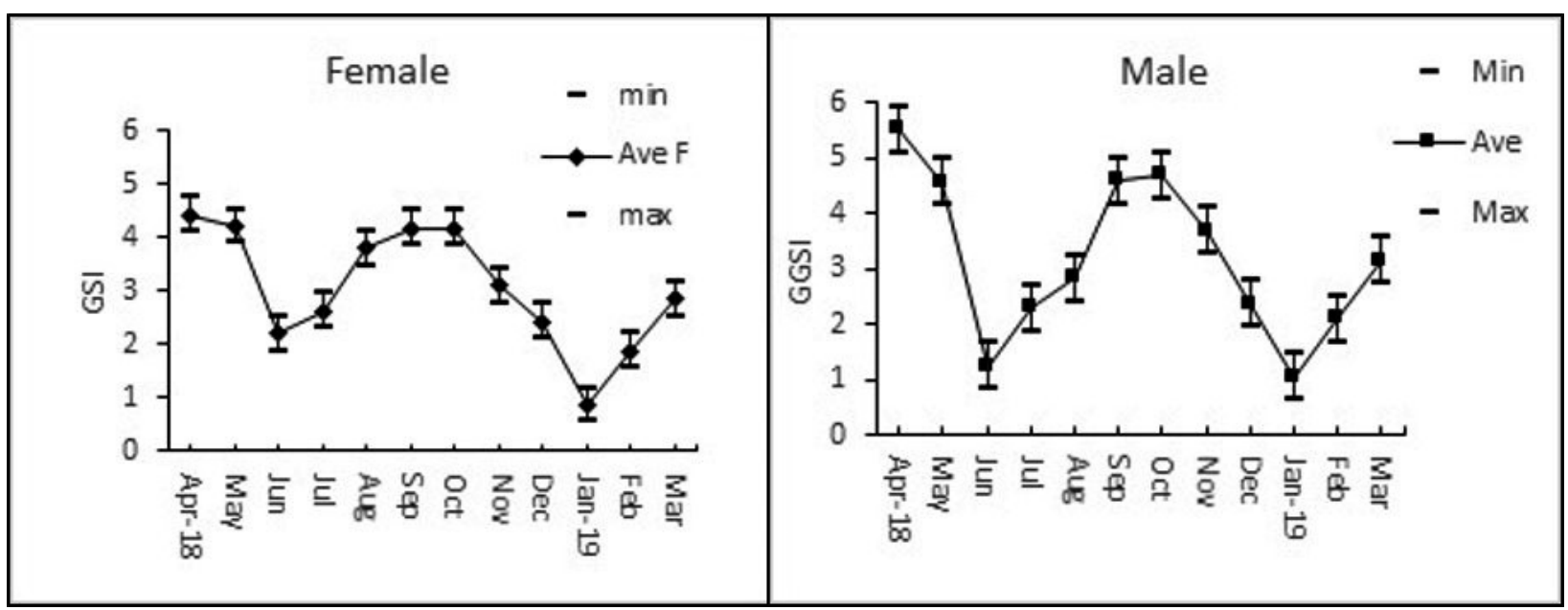

Figure 3. Monthly gonadosomatic index of female and male longtail tuna in the Java Sea.

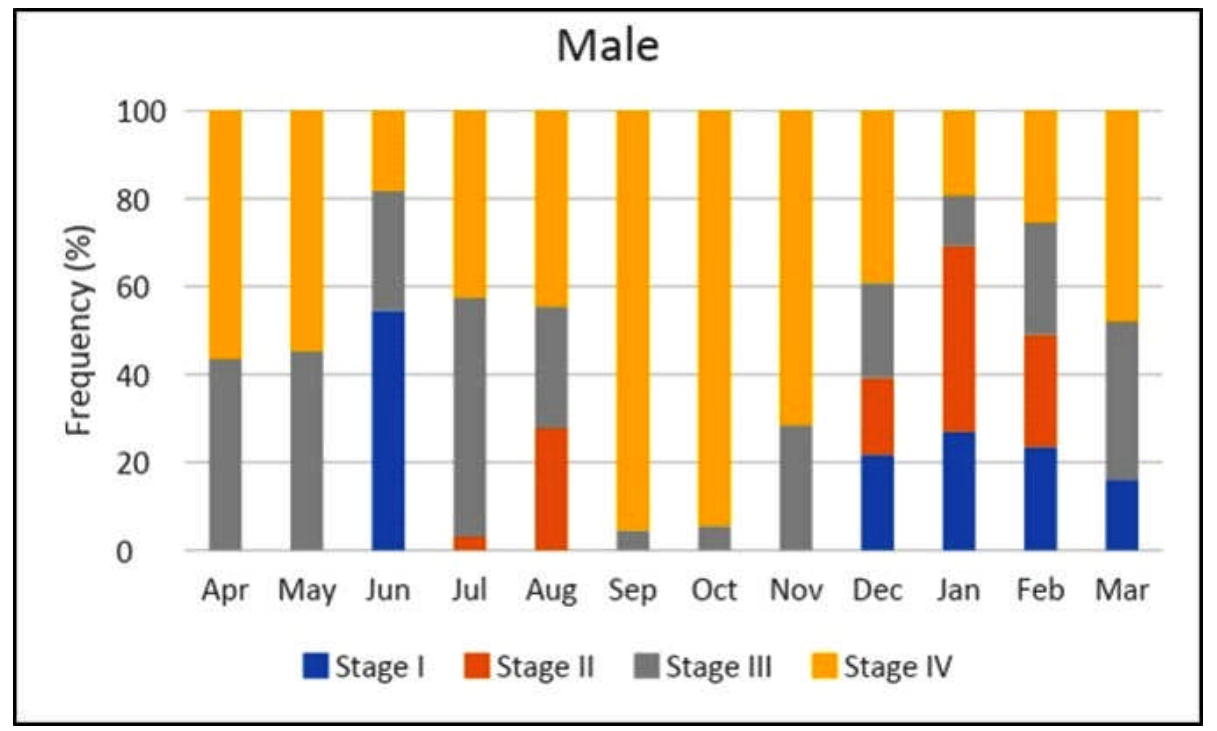

Figure 4. Monthly gonad maturity stages of male longtail tuna in the Java Sea.

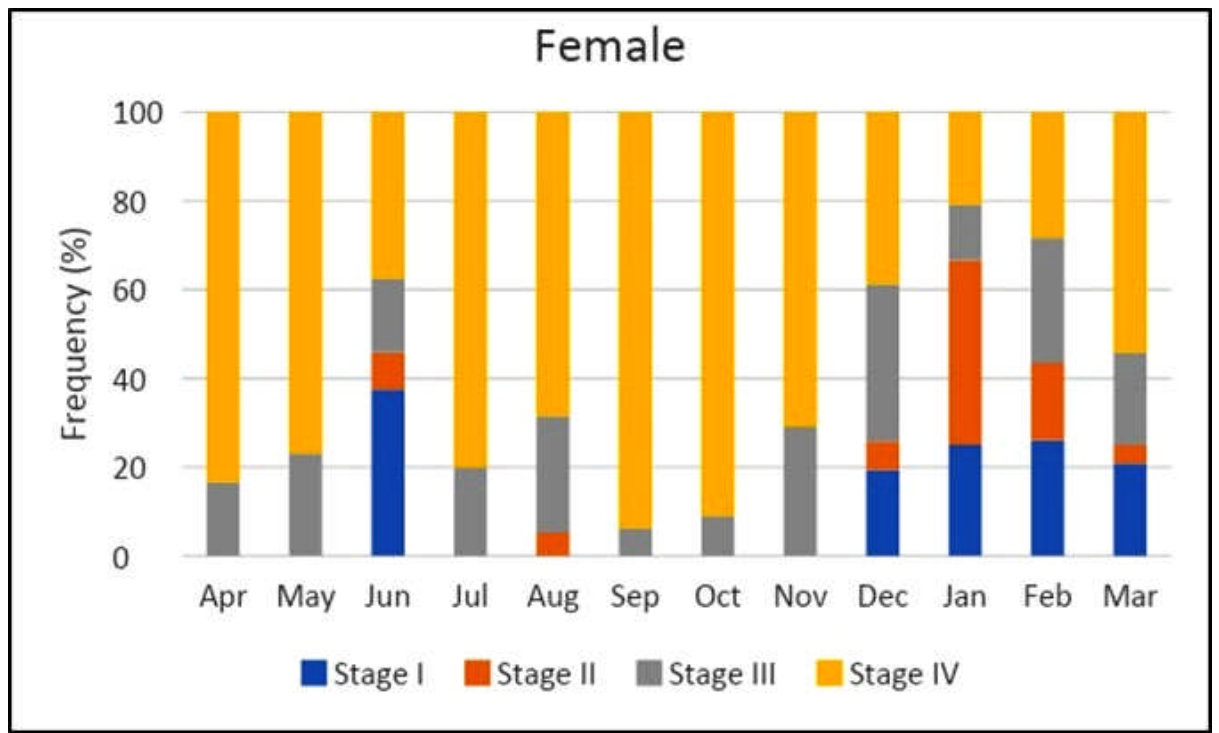

Figure 5. Monthly gonad maturity stages of female longtail tuna in the Java Sea. 


\section{Size at First Capture (Lc) and Size at First Maturity (Lm)}

Estimation of the size at first capture $(L c)$ of longtail tuna from drift gillnet and small purse seine was 43.2 $\mathrm{cm}$ and $26.4 \mathrm{~cm}$, respectively (Figure 6). The estimated size at first maturity using the logistic model was estimated $42.3 \mathrm{~cm}$.

\section{Fecundity and Size of Oocytes}

The fecundity of longtail tuna (Thunnus tonggol) in the Java Sea was $783,597-1,579,160$ eggs, from mature females ranging $38-52 \mathrm{cmFL}$. The oocyte diameter was $0.21-0.99 \mathrm{~mm}$, with average $0.56 \mathrm{~mm}$. The oocyte frequency distribution has two modes (heterogen) (Figure 7).

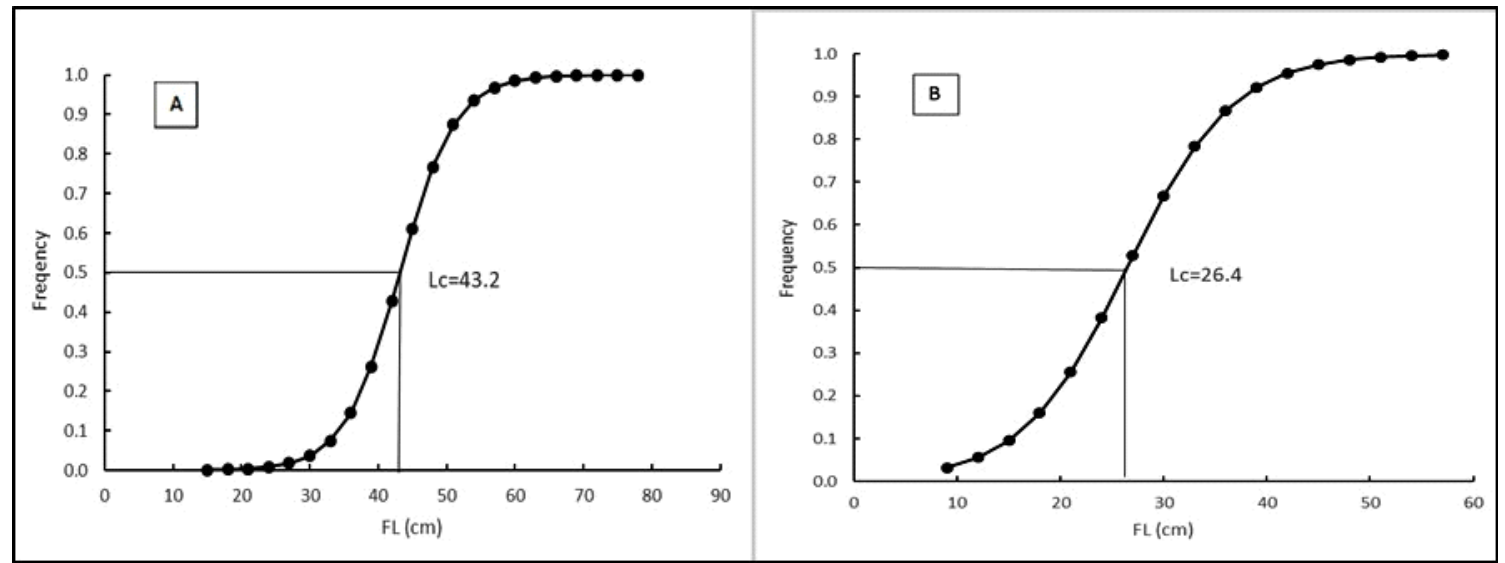

Figure 6. The length at first capture $(L c)$ of longtail tuna caught by drift gillnet $(A)$, and mini purse seine $(B)$.

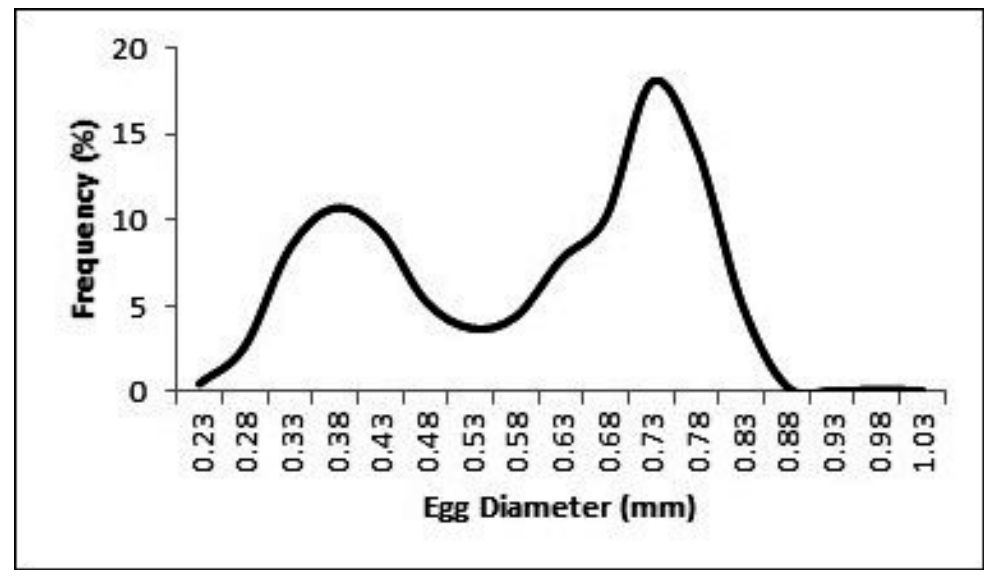

Figure 7. Oocyte diameter of longtail tuna in the Java Sea.

The relationships between fecundity $(F)$ and described in Figure 8 . There are significant positive variables length $(F L)$ as well as body weight $(W)$ are relationships between the fish length or weight and fecundity.

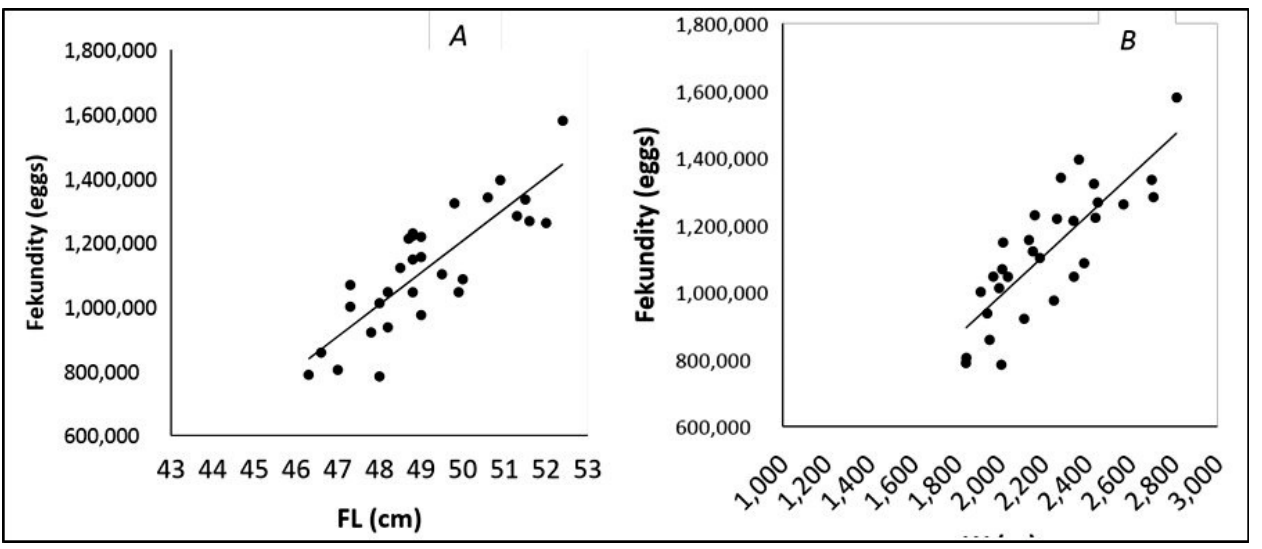

Figure 8. Relationships of fecundity-length (A) and fecundity-weight (B) of longtail tuna. 


\section{Oocyte Development}

The development of oocytes determined based on histological examination showed at least four stages of sexual maturity, while stage $\mathrm{V}$ was not found during this study (Figure 9).

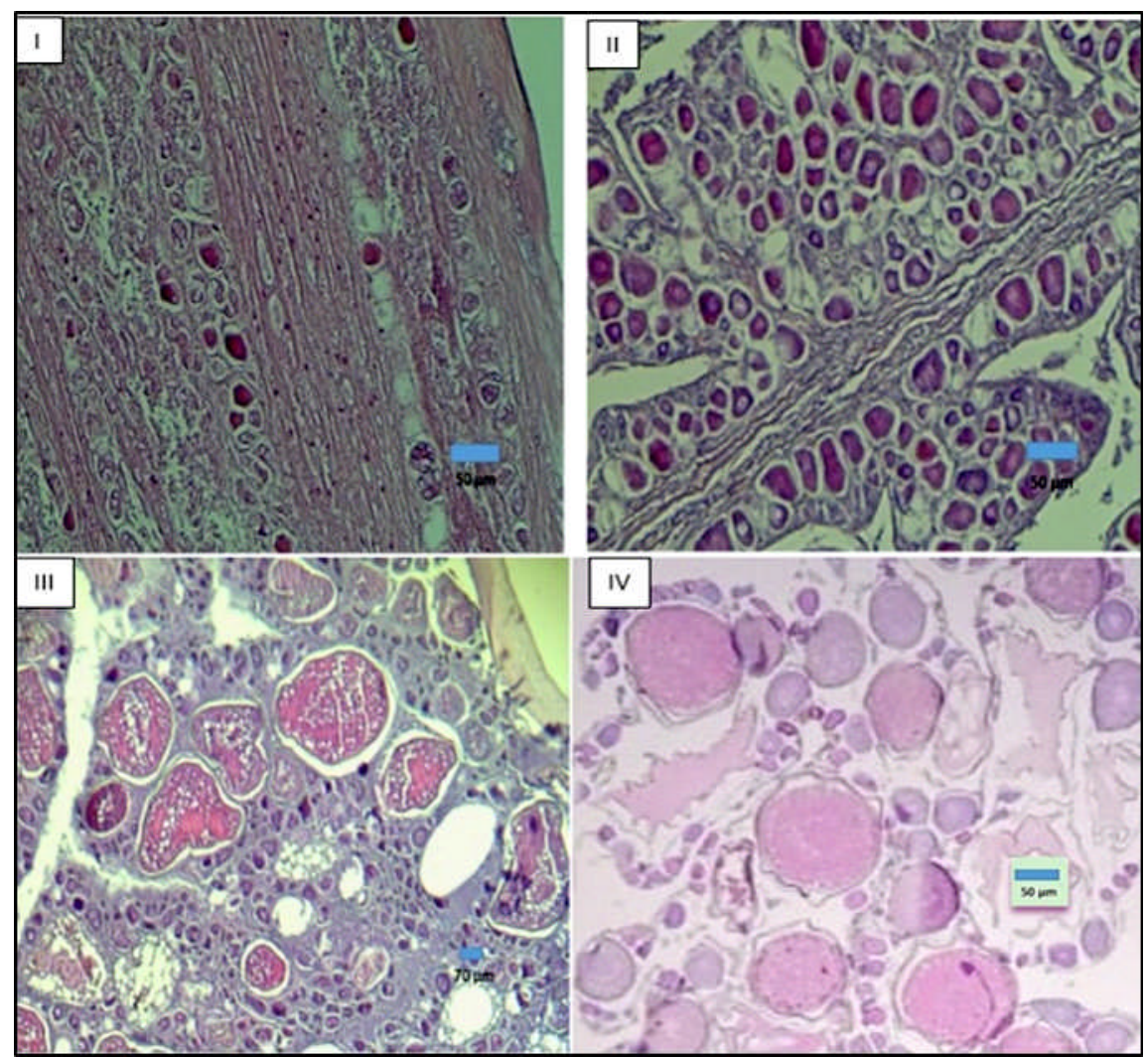

Figure 9. Histological section of the ovaries of longtail tuna in the Java Sea. (I) stage I and (II) stage II: Primary growth oocytes, (III) stage III: Vitellogenesis, (IV) stage IV: Fully yolked oocytes.

Stage I, is still in the oogenesis stage, the gonadal development process of forming an oocyte. The oocyte is still small and the nucleus is round or oval with a thicker cytoplasm. Stage II, oocytes begin to grow and the cell nucleus is appeared to increase in size and the yolk spread. Stage (III) is maturing or vitellogenesis. The amount and size of the yolk is increasing and clearly visible in all areas of the oocyte. Oil droplets appear in the cytoplasm, the cell nucleus concentrated in the central oocyte. Stage IV, is maturation. Plenty of egg yolks reach fully yolked oocytes, oil droplets increasingly spread from around the cell nucleus to the periphery oocytes. The core cells migrate around the oocytes and are usually replaced by larger oil droplets.

\section{Discussion}

The samples used were both male and female fish, which were not separated because longtail tuna is not a dimorphism species, meaning there are no significant differences among external morphological characteristics between male and female (Schaefer,
2001). Furthermore, Griffiths et al. (2017) stated that there were no statistical differences found in the morphometric characteristics between sexes in longtail tuna. The length weight relationship in our study showed that the $b$ value had no significant difference with 3, which indicates an isometric growth pattern. Several studies on length-weight relationship in this species have isometric growth pattern, such as Abdussamad et al. (2012) in Indian waters, Kaymaram et al. (2013) and Yasemi et al. (2017) in Persian Gulf waters, and Hidayat \& Noegroho (2018) in the South China Sea. However, the studies of Ahmed et al. (2016) in Pakistan waters, Griffiths et al., (2017) in Australian waters, Darvishi et al. (2003) and Khorshidian \& Carrara (1993) in the Persian Gulf showed negative allometric growth patterns. These differences in the exponent $b$ value of length-weight relationship are probably related to ecosystem and biological conditions, like spawning period, sexual maturity, feeding behavior, and food competition (Ghosh et al., 2010). Furthermore, Froese (2006) states the variation in the $b$ value could be affected by geographic locations, sampling area, seasons, size 
range, and ecological factors such as temperature. The negative allometric growth of fish might be attributed to the environmental conditions and insufficient food availability (Arslan et al., 2004; Jisr et al., 2018).

The knowledge of sex ratio is important to understand the relationship among individuals, the environment and the state of the population (Vicentini \& Araújo, 2003). The sex ratio of longtail tuna in this study was not significantly different between male and female, showing the similar number of male and female fish in the population. The sex ratio of longtail tuna in other regions of the world was also found not significantly different between male and female (Wilson, 1981; Yesaki, 1982; Griffiths et al., 2010; Hassadee et al., 2014). The insignificant difference between the sexes implies the non-existence of seasonality in sex distribution within the population (Jega et al., 2017). However, the sex ratio may vary from the expected 1:1, influenced by several factors, such as adaptation of the population, reproductive behavior, food availability, and environmental conditions (Vandeputte et al., 2012).

The length at first mature $(L m)$ of longtail tuna caught in the Java Sea on this study was $42.3 \mathrm{~cm}$ FL. The size at first mature ( $\mathrm{Lm})$ of this fish in Thailand waters was $39.6 \mathrm{~cm}$ (Chuenpan, 1985). Thunnus tonggol was reported to attain sexual maturity at 39.6 $\mathrm{cm}$ in the Persian Gulf and the Oman Sea (Hedayatifard, 2007) and at $37 \mathrm{~cm}$ in Taiwan waters (Chiang et al., 2011). Yesaki (1982) and Cheunpan (1984) from Thailand recorded 43 and $40 \mathrm{~cm}$, respectively, as the length at maturity. Pillai and Ganga (1985) and Abdussamad et al., (2012) in Indian waters reported the length at first maturity $(L m 50)$ as 51.1 and $50 \mathrm{~cm}$, respectively. Hidayat \& Tegoeh (2018) stated that the $L m$ value of this fish in the South China Sea was $41.1 \mathrm{~cm}$ FL. It appears that the size at maturity of this species varies in several locations. The differences in size at maturity for the same species may be due to variations in geography and fishing pressure (Morgan \& Colbourne 1999; Claereboudt et al. (2005); Moresco \& de Bemvenuti (2006); (Haig et al., 2015). This variation might be different in environmental variables rather than genetic differences (Duponchelle \& Panfilli, 1998). Tormosova (1983) suggested that stock density, food, and water temperatures may influence the growth of fish and affect the age and size at maturity. Yoneda \& Wright, (2004) stated that variation in size maturity may reflect population differences.

The estimation length at first capture $(L c)$ of longtail tuna from drift gill net and small purse seine was 43.1 $\mathrm{cm}$ and $25.9 \mathrm{~cm}$, respectively, while the length at first maturity $(L m)$ using a logistic model was estimated $42.3 \mathrm{~cm}$. The values of drift gillnet Lc was bigger than its $\mathrm{Lm}$ value, indicating that most of the longtail tuna caught by drift gillnet were the mature fish that had spawned at least once before being caught. This type of fishing gear is recommended. In contrast, the sizes of longtail tuna caught by small purse seine were mostly under the length at first maturity, meaning they were immature fish.

The development of the monthly GSI simultaneously with macroscopic stages showed that both male and female gonad development reached the highest in April and October then decreased in the following month. According to Widodo (1986), King (1995), and Claereboudt et al. (2005), spawning season occured about one month after the highest percentage of mature fish. Therefore, the estimated spawning seasons of longtail tuna in the Java Sea were around May and November. The spawning season of longtail tuna in Thailand waters occurred in May and August (Hassadee et al., 2014), in Indian waters occured in October-November (Abdussamad et al., 2012), and in the waters of Taiwan around December (Wei et al., 2011). The diversity of the spawning season and periodicity exists due to the varied ecological environments (Agarwal, 2008; Jega et al., 2018; Papoulias et al., 2006). The water temperature, photoperiod, and prey items may influence the spawning season of fish (Tormosova, 1983; Papoulias et al., 2006; Ma et al., 2012).

The fecundity of longtail tuna in the present study was estimated between 783,597 - 1,579,160 eggs. The information on the fecundity of longtail tuna is limited. The previous estimates varied between 0.2 and 2.0 million oocytes (Klinmuang, 1978; Wilson, 1981; Hedayatifard, 2007; Abdussamad et al., 2012). Lambert (2008) said that fecundity varies in relation to parental quality (size, condition), food availability, as well as environmental and evolutionary factors (stock biomass, fishing pressure). Jega et al. (2018) stated that the differences in fecundity and reproductive potential were affected by the size of fish, food availability, temperature, salinity and genetics.

The oocytes distribution has more than one modes, especially those in mature fish, indicating that this species was categorized as batch or multiple spawners (Murua \& Saborido-Rey, 2003; LowerreBarbieri et al., 2011; Schaefer, 2001). The histological oocyte development in mature fist (stage III and IV) showed that the oocyte is heterogen, showing that the ovarian development of the longtail tuna belongs to the asynchronous oocyte development group (Murua \& Saborido-Rey, 2003). 


\section{CONCLUSIONS}

The longtail tuna (Thunnus tonggol) in the Java Sea has an isometric growth pattern. The sex ratio was not significantly different between male and female. The longtail tuna tuna caught by drift gill net was mature fish, while from purse seine was immature. The spawning season occurred in May and November, with fecundity ranging $783,597-1,579,160$ eggs. The longtail tuna was multiple spawner, with double spawning pattern.

\section{ACKNOWLEDGEMENTS}

The authors are grateful to the former head of Research Institute for Marine Fisheries (RIMF), the Ministry of Marine Affairs and Fisheries (MMAF), Dr. Fayakun Satria, M.App.Sc and research project coordinator for Fisheries Management Area (FMA) 712 in 2018, Mr. Suwarso, M.Si. This study was supported by RIMF and MMAF. We also would like to thank all scientific enumerators in Pekalongan for contributing in collecting data.

\section{REFERENCES}

Abdussamad, E. M., Said Koya, K. P., Ghosh, S., Rohit, P., Joshi, K. K., Manojkumar, B., Prakasan, D., Kemparaju, S., Elayath, M. N. K., Dhokia, H. K., Sebastine, M., \& Bineesh K. K. (2012). Fishery, biology and population characteristics of longtail tuna, Thunnus tonggol (Bleeker, 1851) caught along the Indian coast. Indian J. Fish. 59(2), 716. http://eprints.cmfri.org.in/id/eprint/8985

Agarwal, N. K. (2008). Fish reproduction, New Delhi APH Pub, Corp. p. 157

Ahmed, Q., Bilgin, S., Bat, L. (2016). Length based growth estimation of most commercially important Scombridae from offshore water of Pakistan Coast in the Arabian Sea. Turkish Journal of Fisheries and Aquatic Sciences 16: 155-167. DOI: 10.4194/ 1303-2712-v16_1_16.

Arslan, M., Yildirim, A., \& Bektas, S. (2004). Length weight relationship of Brown Trout, Salmo trutta, inhabiting Kan Stream, Coruh Basin, North-Eastern Turkey. Turk. J. Fish. Aqua. Sci. 4, 4548. [Google Scholar]

Cheunpan, A. (1984). Sexual maturity, size at maturity and spawning season of longtail tuna ( $T$. tonggol), eastern little tuna ( $E$. affinis) and frigate mackerel (A. thazard) in the Gulf of Thailand.
Fisheries Report of the Marine Fisheries Division of the Department of Fisheries, Bangkok. 43, 33.

Collete, B.B., \& Nauen, C.E. (1983). FAO Special Catalogue. Vol. 2 Scombrids of the world an annotated and illustrated catalogue of tunas, mackerels, bonitos, and related species known to date. FAO Fisheries Synopsis.125(2), 92-93.

Claereboudt, M. R., Mcllwain, J. L., Al-Oufi, H. S., \& Ambu-Ali, A. A. (2005). Patterns of reproduction and spawning of the kingfish (Scomberomorus commerson, Lacépède) in the coastal waters of the Sultanate of Oman. Fish. Res. 73(3), 273282. https://doi.org/10.1016/j. fishres.2005.02.009.

Darvishi, M., \& Salarpur, A. (2003). Spawning, fecundity and feeding of longtail tuna (Thunnus tonggol) in the Persian Gulf and Oman Sea (Hormuzgan province). Animal and Fisheries Sciences 16 (2), 70-75. DOI: 10.22092/ ijfs.2018.116992.

DGCF. (2017). Directorate general of capture fisheries. Statistics of marine capture fisheries production 2005-2016. Jakarta (ID): Ministry of Marine Affairs and Fisheries Republic of Indonesia.

Duponchelle, F., \& Panfilli, J. (1998). Variation in age and size of maturity of female Nile tilapia Oreochromis niloticus, population from man-made lakes of Cote d'Ivoire. Environmental Biology of Fishes. 52, 453-465.

Effendie, M. I. (2002). Fisheries Biologi. Yayasan Pustaka Nusantara. Bogor. p.163 in Indonesian.

Froese, R., \& Pauly, D. E. (2020). FishBase, version 02/2020. www.fishbase.org. Accessed at 26-082020.

Froese, R. (2006). Cube law, condition factor and weight-length relationships: history, meta-analysis and recommendations. Journal of Applied Ichthyology, 22, 241-253.doi:10.1111/j.14390426.2006.00805.x

Ghosh, S., Pillai, N. G. K., \& Dhokia, H. K. (2010). Fishery, population characteristics and yield estimates of coastal tunas at Veraval. Indian Journal of Fisheries, 57(2), 7-13. https:// onlinelibrary.wiley.com/doi/10.1111/j.14390426.2006.00805x/ 
Griffiths, S.P., Pepperell, J.G., Tonks, M.L., Sawynok, W., Olyott, L., Tickell, S., Zischke, M.T., Burgess, J., Jones, E., Joyner, D., Lynne, J., Makepeace, C. \& Moyle, K.. (2010). Biology, fisheries and status of longtail tuna (Thunnus tonggol), with special reference to recreational fisheries in Australian waters. FRDC Final Report 2008/058. p. 101.

Griffiths, S. P., Fry, G. C., Manson, F. J., Pillans R. D. (2017). Morphometric relationships for four Scombridae fish species in Australian waters. J. Appl. Ichthyol. 33 (3); 583-585. DOI: 10.1111/ jai. 13136.

Haig, J. A., Pantin, J. R., Salomonsen, H. (2015). Temporal and spatial variation in size at maturity of the common whelk (Buccinum undatum). ICES Journal of Marine Science, 72 (9), 1-13. DOI: 10.1093/icesjms/fsv128.

Hassadee, P., Yakoh, A., Nootmorn, P., Puntuleng, P., Songkaew, N., \& Kruanium, U. (2014). Reproductive biology of longtail tuna in Thai Waters. IOTC-2014-WPNT 04-27. P: 1-9.

Hedayatifard, M. (2007). The surveying of biological characteristics of long tail tuna (Thunnus tonggol) in the southern coasts of Iran. Proceedings of the International Conference on Science and Technology of Aquaculture, Fisheries and Oceanography in the Arabian Seas, 10-13 February 2007. State of Kuwait, p. 1-11.

Hidayat, T. \& Noegroho, T. (2018). The Biology reproduction of longtail tuna (Thunnus tonggol) in the South China Sea. BAWAL. 10(1), 17-28. In Indonesian with English abstract.DOI:http:// dx.doi.org/10.15578/bawal.10.1.2018.17-28

Holden, M.J., \& Raitt, D.F.S. (1974). Manual of Fisheries Science. FAO Fish. Tech. Pap. 115. 1214p. Rome, Italy. http://www.fao.org/3/F0752E/ F0752E05.htm\#ch5.2.2

Jega, I. S., Miah, M. I, Haque, M. M., Shahjahan, M., Ahmed, Z. F., \& Fatema, M. K. (2017). Sex ratio, length-weight relationships and seasonal variations in condition factor of menoda catfish Hemibagrus menoda (Hamilton, 1822) of the Kangsha River in Bangladesh. International Journal of Fisheries and Aquatic Studies. 5(5), 49-54. DOI: 10.3923/ jfas.2018.39.48

Jega, I. S., Miah, M. I., Huda, N. A, Rahman, M. A, Fatema, M.K, Haque, M. M., \& Shahjahan, M. (2018). Reproductive Biology of the Threatened
Menoda Catfish Hemibagrus menoda (Hamilton, 1822) in the Kangsha River, Bangladesh. Journal of Fisheries and Aquatic Science. J. Fish. Aquat. Sci. 13 (1), 39-48. DOI: 10.3923/jfas.2018.39.48.

Jisr, N., Younes, G., Sukhn, C., \& El-Dakdouki, M.H. (2018). Length-weight relationships and relative condition factor of fish inhabiting the marine area of the Eastern Mediterranean city, Tripoli-Lebanon. Egyptian Journal of Aquatic Research. 44, 299305. https://doi.org/10.1016/j.ejar.2018.11.004.

Kaymaram, F, Darvishi, M., Behzadi, S., Ghasemi, S. (2013). Population dynamic parameters of Thunnus tonggol in the north of the Persian Gulf and Oman Sea. Iranian Jour. of Fish. Sci. 12(4), 855-863. [Google Scholar]

Klinmuang, H. (1978). Preliminary studies on the biology of tunas in the west of the Gulf of Thailand and off the east coast of Peninsular Malaysia. Fisheries Report of the Marine Fisheries Division of the Department of Fisheries, Bangkok, 5, 27 p.

Khorshidian, K., \& Carrara, G. (1993). An analysis of length frequency of Thunnus tonggolin Hormozgan water. In : Ardill J.D. (ed). Proceeding of the expert consultation on Indian Ocean Tunas, 5th Session. Mahe, Seychelles. P. 275.

Koya, K. M., Rohit, P., Abdussamad, E. M., Azeez, P. A., Vase, V. K., \& Bharadiya, S. (2018). Reproductive biology, diet and feeding pattern of longtail tuna Thunnus tonggol (Bleeker, 1851) in the north-eastern Arabian Sea off Gujarat, India. Indian J. Fish., 65 (2), 16-25. DOI: 10.21077/ ijf.2018.65.2.78457-02.

King, M. (1995). Fisheries biology, assessment, and management (p. 341). Blackwell Science Ltd.

Lambert, Y. (2008). Why should we closely monitor fecundity in marine fish populations? Journal of Northwest Atlantic Fisheries Science. 41, 93-106. https://doi.org/10.2960/J.v41.m628.

Lowerre-Barbieri, S. K., Ganias, K., Saborido-Rey, F., Murua, H., \& Hunter, J.R. (2011). Reproductive Timing in Marine Fishes: Variability, Temporal Scales, and Methods. Marine and Coastal Fisheries, Dynamic and Management Ecosystem Science. 3(1), 71-91. doi:10.1080/ 19425120.2011.556932,

Ma, B., Xie, C., Huo, B., Yang, X., \& Chen, S. (2012). Reproductive biology of Schizothorax o'connori 
(Cyprinidae: Schizothoracinae) in the Yarlung Zangbo River, Tibet. Zoological Studies. 51(7), 1066-1076.

Morgan, M. J., \& Colbourne, E. B. (1999). Variation in maturity-at-age and size in three populations of American plaice. ICES Journal of Marine Science. 56, 673 - 688. https://doi.org/10.1006/ jmsc.1999.0487.

Moresco, A., \& de Bemvenuti, A. (2006). Reproductive biology of silverside Odontesthes argentinensis (Valenciennes) (Atherinopsidae) of coastal sea region of the South of Brazil. Revista Brasiliera de Zoology. 23 (4),1168-1174. https://doi.org/10.1590/ S0101-81752006000400025

Murua, H., \& Saborido-Rey, F. (2003). Female reproductive strategies of marine fish species of the North Atlantic. Journal of Northwest Atlantic Fishery Science. 33, 23-31. [Google Scholar]

Muthiah, C. (1985). Fishery and bionomics of tunas at Mangalore. In: Silas, E. G. (Ed.), Tuna fisheries of the exclusive economic zone of India: biology and stock assessment. Bull. Cent. Mar. Fish. Res. Inst., Cochin. 36, 51-70. [Google Scholar]

Pekalongan Fishing Port Nusantara. (2016). Statistics of Captured Fisheries 2016. In Indonesian.

Papoulias, D. M., Chapman, D., \& Tillitt, D. E. (2006). Reproductive condition and occurrence of intersex in bighead carp and silver carp in the Missouri River. Hydrobiologia (2006) 571, 355-360. DOI: 10.1007/s10750-006-0260-7

Schaefer, K.M. (2001). Reproductive Biology of Tunas. In: Block, B.A. \& Steven, E.S (eds). Tuna: Physiology, Ecology and Evolution. Academic Press. London. $468 \mathrm{p}$.

Sokal, R. R., \& Rohlf, F. J. (1987). Introduction to biostatistics, 2nd edn. Freeman Publication, New York. $363 \mathrm{p}$.

Sparre, P., \& Venema, S.C. (1998). Introduction to tropical fish stock assessment. FAO Fisheries Technical Paper, Rome. 407p

Sugiyono. (2004). Nonparametric statistic for Research. Penerbit CV. Alfabeta, Bandung: vi+306.

Sujatha, K., Shrikanya, K. V. L., \& Iswarya Deepti, V. A. (2014). Species diversity and some aspects of reproductive biology and life history of groupers
(Pisces: Serranidae: Epinephelinae) off the central eastern coast of India. Marine Biology Research. 11(1), 18-33. doi:10.1080/17451000.2014.949271

Tormosova, I. D. (1983). Variation in the age at maturity of the North Sea haddock, Melanogrammus aeglefinus (Gadidae). J. Ichthyol. 23, 68-74.

Vandeputte, M., Quillet, E., \& Chatain, B. (2012). Are sex ratios in wild European sea bass (Dicentrarchus labrax) populations biased? Aquat Living Resour. 25, 77-81. DOI: 10.1051/alr/ 2012002.

Vicentini, R. N., Araújo, F. G. (2003). Sex ratio and size structure of Micropogonias furnieri (Desmarest, 1823) (Perciformes, Sciaenidae) in Sepetiba Bay, Rio de Janeiro, Brazil. Braz. J. Biol. 63, 559-566. DOI: 10.1590/s151969842003000400003.

Wei, C. C., Hong, H. H., Shin, C. F., Shin, C. C., Chi, L. S., Wen, Y. C., Don, C. L., \& Wei, C. S. (2011). Reproductive biology of longtail tuna (Thunnus tonggol from coastal waters off Taiwan. IOTC2011-WPNT01-30. 1-15 p.

Wilson, M. A. (1981). The biology, ecology and exploitation of longtail tuna, Thunnus tonggol (Bleeker) in Oceania. M.Sc. Thesis. School of Biological Sciences, Macquarie University, Sydney, $195 \mathrm{p}$.

Wujdi, A., Suwarso. (2014). Fluctuation and catch composition of neritic tuna species caught by gillnet in the South China Sea waters. J. Lit Perik. Ind. 20 (4), 207-214. In Indonesian with English abstract. DOI: http://dx.doi.org/10.15578/ jppi.20.4.2014.207-214

Yasemi, M., Bajgan, A. N., \& Parsa, M. (2017). Determining the growth and mortality parameters of longtail tuna (Thunnus tonggol Bleeker, 1851) using length frequency data in coastal water of northern Persian Gulf and Oman Sea, Iran. Int. Aquat. Res. DOI: 10.1007/s40071-017-0170-5.

Yesaki, M. (1982). Biological and environmental observations. A report prepared for the Pole-andLine Tuna Fishing in Southern Thailand Project. FAO FI: DP/THA/77/008: Field Doc. 3, 46.

Yesaki, M. (1994). A review of the biology and fisheries for longtail tuna (Thunnus tonggol) in the IndoPacific Region. FAO Fisheries Technical Paper. 336, 370. 
Ind.Fish.Res.J. Vol. 26 No. 2 December 2020: 119-131

Yoneda, M., \& Wright, P.J. (2004). Temporal and spatial variation in reproductive investment of Atlantic cod, Gadus morhua, in the northern North

Sea and Scottish west coast. Mar Ecol Prog Ser. 276: $237-248$. 
Appendix 1. A five-point maturity scale for partial spawners

\begin{tabular}{|c|c|c|}
\hline Stage & State & Description \\
\hline I & Immature & $\begin{array}{l}\text { Ovary and testis about } 1 / 3 \text { rd length of body cavity. } \\
\text { Ovaries pinkish, translucent; testis whitish. Ova not } \\
\text { visible to naked eye. }\end{array}$ \\
\hline II & $\begin{array}{l}\text { Maturing virgin and } \\
\text { recovering spent }\end{array}$ & $\begin{array}{l}\text { Ovary and testis about } 1 / 2 \text { length of body cavity. Ovary } \\
\text { pinkish, translucent; testis whitish, more or less } \\
\text { symmetrical. Ova not visible to naked eye. } \\
\text { Ovary and testis is about } 2 / 3 \text { rds length of body cavity. }\end{array}$ \\
\hline III & Ripening & $\begin{array}{l}\text { Ovary pinkish-yellow colour with granular appearance, } \\
\text { testis whitish to creamy. No trans- parent or translucent } \\
\text { ova visible. }\end{array}$ \\
\hline IV & Ripe & $\begin{array}{l}\text { Ovary and testis from } 2 / 3 \text { rds to full length of body cavity. } \\
\text { Ovary orange-pink in colour with conspicuous superficial } \\
\text { blood vessels. Large transparent, ripe ova visible. Testis } \\
\text { whitish- creamy, soft. }\end{array}$ \\
\hline V & Spent & $\begin{array}{l}\text { Ovary and testis shrunken to about } 1 / 2 \text { length of body } \\
\text { cavity. Walls loose. Ovary may contain remnants of } \\
\text { disintegrating opaque and ripe ova, darkened or } \\
\text { translucent. Testis bloodshot and flabby. }\end{array}$ \\
\hline
\end{tabular}

